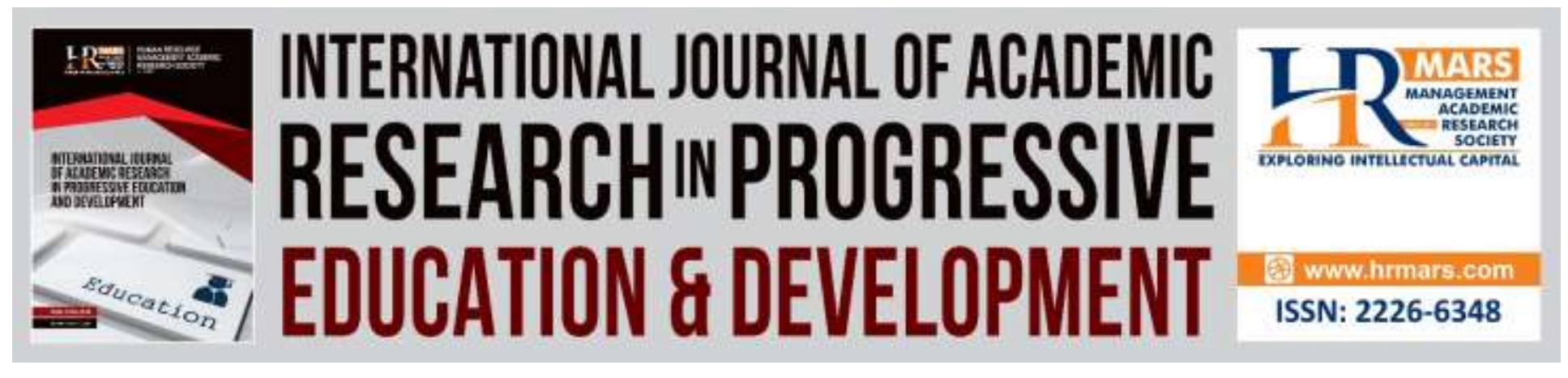

\title{
A Digital Supportive Tool for Assessing Sustainability in Programme Courses: A Case of Universiti Sains Malaysia
}

Siti Fairuz Mohd Radzi, Mohd Sayuti Hassan

To Link this Article: http://dx.doi.org/10.6007/IJARPED/v8-i2/6157 DOI: 10.6007/IJARPED/v8-i2/6157

Received: 12 Jan 2019, Revised: 15 Feb 2019, Accepted: 01 March 2019

Published Online: 24 March 2019

In-Text Citation: (Radzi \& Hassan, 2019)

To Cite this Article: Radzi, S. F. M., \& Hassan, M. S. (2019). A Digital Supportive Tool for Assessing Sustainability in Programme Courses: A Case of Universiti Sains Malaysia. International Journal of Resaeach in Progressive Education and Development, 8(2), 494-506.

Copyright: (C) 2019 The Author(s)

Published by Human Resource Management Academic Research Society (www.hrmars.com)

This article is published under the Creative Commons Attribution (CC BY 4.0) license. Anyone may reproduce, distribute, translate and create derivative works of this article (for both commercial and non-commercial purposes), subject to full attribution to the original publication and authors. The full terms of this license may be seen

at: http://creativecommons.org/licences/by/4.0/legalcode

\section{Vol. 8(2) 2019, Pg. 494 - 506}

http://hrmars.com/index.php/pages/detail/IJARPED

JOURNAL HOMEPAGE

Full Terms \& Conditions of access and use can be found at http://hrmars.com/index.php/pages/detail/publication-ethics 


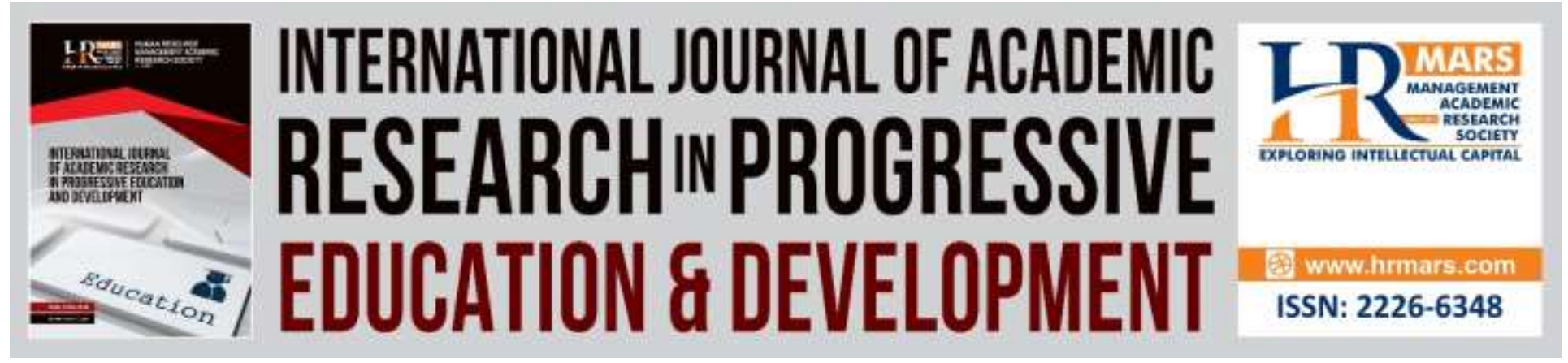

\title{
A Digital Supportive Tool for Assessing Sustainability in Programme Courses: A Case of Universiti Sains Malaysia
}

\author{
Siti Fairuz Mohd Radzi, Mohd Sayuti Hassan \\ Centre for Global Sustainability Studies, Universiti Sains Malaysia, 11800 Penang, Malaysia. \\ Email: fairuzradzi@usm.my
}

\begin{abstract}
Universiti Sains Malaysia (USM) has started to embark its journey towards becoming a sustainability-led university soon after being coveted the Accelerated Programme of Excellence (APEX) in 2008. Embedding sustainability relevant topics in the teaching and research missions is imperative to expedite USM in achieving its vision. Thus, a tool is required to ensure that the sustainability assessment of all programmes offered in USM is carried out systematically and efficiently. The purpose of this study is to assess the sustainability content of 18 programmes offered in USM. The sustainability content of each programme's curriculum is measured and assessed by using World University Sustainability Assessment (WUSA), a digital tool that is designed to help universities, educational institutions, as well as practitioners in sustainable development field or any related field to assess the sustainability content of any manuscripts. The result suggested that the relevant schools in USM that offer the programmes should revise the programme curricula thoroughly to ensure that more sustainability relevant topics are embedded into the curricula. The main limitation of the study is that the study only employed the programme book from each of the programme, which contains the synopsis of the programme and courses offered to prospective students to assess the sustainability content. This paper will be useful to the management of each school in the university in incorporating sustainability element in all of the programmes offered to prospective students.
\end{abstract}

Keywords: Sustainability, Sustainability Curriculum, Sustainable Development, Sustainability Education, Education for Sustainability

\section{Introduction}

Sustainability and sustainable development have become one of the dominant topics of discussion among individuals, institutions, companies and universities in response to any global issues with regard to climate change. Since the definition of sustainability is still vague, most researchers always refer to the Bruntland Report (WCED, 1987) which came out with the characteristic definition of sustainability which is, "the development that meets the needs of the 
present without compromising the ability of future generation to meet their own needs". Some companies and universities are starting to become more au courant with sustainability aspect in term of the way that the companies and universities are administered and the way the stakeholders work within the said environment. USM is among the universities which strive towards incorporating sustainability within the university's environment. Since 2008, USM has long incorporated sustainability as one of its thrusts (Razak and Mohamed, 2008) to transform the university into becoming a world class sustainability-led university. The university tries to embark sustainability aspect in each programme offered by the university in order to ensure that sustainability is adapted within the teaching and learning environment. Ongoing efforts, such as adjusting the current curriculum to integrate sustainability education, have been placed accordingly to ensure that sustainability is introduced and taught to students in the university. The problem that some universities including USM are currently facing is that it consumes a lot of time and efforts to monitor the curriculum content of each school or faculty as universities house many academic schools or faculties, and research centres. Thus, in order to ensure that the monitoring process of curriculum enhancement in each school, faculty, and research centre is carried out in a systematic manner, a digital tool is developed to help academic administration to calculate the percentage of sustainability content of the current curriculum of each school.

The main purpose of the paper is to study how far sustainability is incorporated in the current curriculum in Malaysian education context and how sustainability is usually assessed. This paper then introduces a tool to help assessing sustainability content in a fast manner. This study has assessed the sustainability content in 18 programmes offered by different schools in USM. Only 18 out of 71 programmes were chosen as the subject matter due to time constraint as well as these programmes are the only programmes that have the latest and complete course synopsis book at the moment. USM has developed an assessment tool called World University Sustainability Methodology (WUSA); previously known as Sustainability Assessment Methodology (SAM) to assess the sustainability content of a document instantly. The assessment tool uses indicator-based methodology to assess the sustainability content in documents such as book, project report, course synopsis, student's assignment and many more.

\section{Literature Review}

\section{Curriculum-Educational Issues}

Transformation occurs not only in the educational organisation, but also in its curriculum. This is in line with the aim of most universities to not only be a place to prepare students to fill specific job vacancies in the future, but also as a place that functions to provide a perfect and complete education that guarantees and enables them to contribute towards their self-development as well as the development of the people. It means that educational curriculum must possess a way or mechanism that focuses on the process of developing individual potentials from all angles. The educational curriculum has gone through various transformations and changes since the early existence of the national education system.

Presently, after entering the new millennium of the $21^{\text {st }}$ century, the global community has passed through another phase of paradigm shift in life. These changes covers the shift from being an industrial community to being an informative community; from using human technology to 
using high innovation technology devices; from the concept of power centralisation to the concept of power distribution; from using the hierarchical concept to using the networking concept; from involvement in the local economy to involvement in the international economy; and from using the concept of short-term planning to using the concept of long-term planning.

According to the Ministry of Education Malaysia (MOE, 2001), education development from the Era of Policy Development to the Era of National Vision Policy has succeeded in achieving numerous improvements, specifically in providing infrastructure, educational facilities, and teaching training. The strategy to enhance education opportunity has achieved its goal successfully. However, presently, various issues have been raised regarding the achievement of the National Education Policy. Among the issues raised are related to education structure, access to education, equity, teachers' quality, imbalance of infrastructure preparation, and curriculum relevance. This is in line with the opinion of Hussin (2004) who stated that many of the education issues can be categorised into administration, educational level, education technology, school organisation, and teacher training.

Several issues that are related to the education structure such as the current curriculum does not cover sustainability, in that it does not really fulfil the requirements. For example, in the analysis of curriculum in 18 programmes in USM by using WUSA, this study found that the curricula are not sustainable (see Table 1). In each of the criteria for sustainability, the percentage is below average.

\section{Sustainability in Education}

Education for sustainability refers to a learning that is needed to conserve and improve quality of life for future generations (Majzub, 2005). In December 2002, UNESCO has announced that the year 2005 until 2014 as the education decade for sustainable development. UNESCO has laid out the definition of education for sustainability as: education which "includes key sustainable development issues into teaching and learning; for example, climate change, disaster risk reduction, biodiversity, poverty reduction, and sustainable consumption. It also requires participatory teaching and learning methods that motivate and empower learners to change their Sustainability 2015, 715696 behavior and take action for sustainable development" (Pauw et. al, 2015).

Each country will have to ensure that improvement to education system is a continuous effort to enhance individual potentials in a complete and integrated manner to develop well-balanced and harmonic individuals with high morale. This clearly shows the efforts to produce a progressive community that can contribute to the development of the country. Continuous efforts are required to further enhance individual potentials, and develop well-balanced and harmonic individuals with high morale. The aim is to conserve and ensure a better life quality of the future generations. Hence, Education for Sustainable Development at school or faculty hopes to achieve the objective and fulfil the concept of educational sustainability. According to Mohamad (2001), sustainable development through education is the latest innovation in education reform, which 
starts from natural environment education. Education for Sustainable Development enables human beings to build knowledge, values, and skills to participate in decision making to do something, individually or collectively, locally or globally that will enhance life quality in the present without damaging the future of the planet.

Furthermore, Hopkins (2005) mentioned that even though the world community acknowledges the importance of education to achieve sustainable development, it is unfortunate that up until now the achievement is still limited. Nations University (UNU) and Institute of Advanced Studies (IAS), European Network of the UNESCO, International Forum on Education for Sustainable Development, Beijing has conducted discussions and forums, however, the implementation of education for Sustainable Development is quite slow. Education systems in most countries do not carry out learning activities that focus attention to the main issues in sustainable development. In 2006, a research by UN Economic Commission for Europe (UNECE) has identified several issues and constraints in the implementation of education for sustainable development. Among the issues identified were lack of understanding on the concept of sustainable development, poor understanding of the meaning of education for sustainable development, and lack of allocation to carry out projects related to education for sustainable development. In addition, the lack of support and the role played by other bodies, be it the government or nongovernment as well as media towards education for Sustainable Development, affects the ability of teachers and administrators to understand the meaning of ESD. On the other hand, in vocational education, ESD is only understood in its narrow sense.

Other studies such as Pavlova $(2004,2006)$ and Pavlova and Lebeame (2004) in France, Australia, and Russia obtained perceptions from technology-based teachers towards sustainability. These studies focused on sustainability issues in the syllabus of technical subjects. Results from the studies showed that technology-based teachers do not participate in education for sustainable development. Most pre-service teachers and teachers who teach in the three countries do not possess a fair level of knowledge on the concept of sustainable development or education for sustainable development. Therefore, Pavlova (2008) suggested a guideline for teachers in implementing the concept of education for sustainable development through teaching and learning.

\section{Sustainable Development Strategy for Education}

According to the Bonn Declaration (2004), education for sustainable development should be able to ensure workers have the knowledge, competency, skills, values and attitude to become responsible and productive citizens who always appreciate the execution of good work and to produce a sustainable community. Furthermore, sustainable development would renew the skills of individuals. Studies on labour market have shown that labour should be aware of the rules and conditions of certain skills and the transformation in the working world. Among the requirements that every worker must possess are knowledge worker (k-worker) skills, generic or soft skills, retraining, continuous learning, workers' role in community, skills development, commitment and motivation, knowledge economy (k-economy), critical thinking, and problem-solving skills. In the context of Malaysia, to achieve Vision 2020, Malaysia needs more k-worker (Yunos, 2004). 
Meanwhile, teachers should also possess high knowledge and skills in the field that they teach. This is necessary so that teachers can be more confident in their teaching because it will eventually affect the students they teach (Ishak, 2002). Hence, re-orientation towards sustainable development needs to be made not only to the contents of the courses and to the curriculum development, but also to the whole teaching system. It must also include implementation, policy development, administration, training for teachers and allocation (UNESCO-UNEVOC,2004). In addition, UNEVOC has highlighted some sustainability strategies to be taken into consideration to ensure sustainable development in teaching can be well implemented. In particular, UNEVOC has highlighted the following seven strategies, summarised as (a) support and country's vision, (b) support and study the country's policy, (c) guidelines for planning and implementation, (d) capacity building and training programme, (e) support the development of material resource and learning equipment, $(f)$ establish relationship and partnership, and (g) continuous monitoring, evaluation, and research.

Therefore, WUSA that has been developed by USM can help in terms of measuring the level of sustainability for each programme being planned for implementation. Programmes such as enhancing the knowledge, competencies, skills, values, and attitude should be emphasised more in the curriculum content to develop responsible and productive citizens, knowledgeable workers, workers with generic or soft skills, workers that are capable of playing their role in the community, willing to participate in skills development, and have the commitment and motivation, and knowledge about k-economy.

\section{Methodology}

The Centre for Global Sustainable Studies (CGSS), one of research centres in USM, has developed WUSA, a new digital tool for monitoring sustainability mainstream throughout USM, in keeping with its current vision of "Transforming Higher Education for a Sustainable Tomorrow". WUSA (refer Figure 1) is a digital indicator-based methodology which is developed by a sustainability team which consists of academicians and programmers from CGSS USM. WUSA, introduced in 2015, has been used by USM to assess the sustainability content of any documents such as sustainability related reports, research projects, academic course, and knowledge transfer programme. WUSA is developed as a method to help the university in assessing the sustainability content of a document in an effective and efficient manner without any biases against the result. This is because the result will be generated automatically by the software which is equipped with calculation algorithm and keywords. So long as there is documented evidence, WUSA can help to make an assessment of its sustainability content. Furthermore, WUSA has been recognized by the Ministry of Higher Education, Malaysia and has received a silver medal in the International Conference and Exposition on Inventions by Institutions of Higher Learning (PECIPTA) in 2015. 


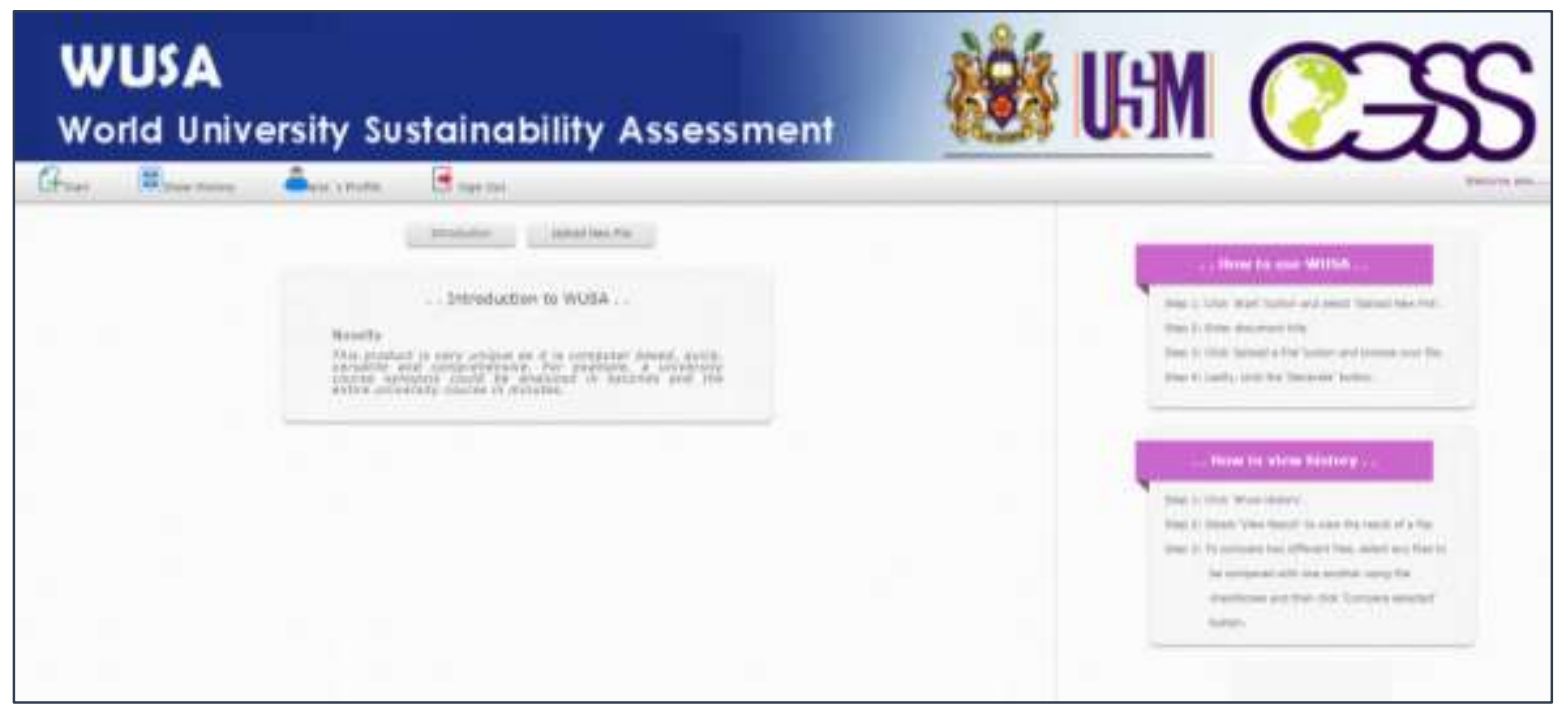

Figure 1 User interface of WUSA

WUSA aims to provide feedback and guidance to all practitioners in USM to build sustainability content in their mission activities. This may include re-orienting the existing courses or designing and managing new research and community-oriented projects. In aggregate, the results may be used either for rating or for ranking sustainability performance of each school and centre in USM.

WUSA uses a set of Sustainability Indicators (SI) which is used to assess the sustainability content of existing courses, subjects, research projects, and community initiatives. The SI has been identified in the keyword extraction process by using SPSS and aligned to USM Accelerated Programs for Excellence (USM-APEX) sustainability roadmap which is used to assist in evaluating, designing, and implementing sustainability mainstream in teaching, research, community engagement and institutional arrangement throughout the university.

WUSA, as a holistic set of sustainability indicators, is important to USM. This is because USM adopts the standpoint that sustainability integration must be implemented at all levels of activities in its departments, as these activities have been synchronized with its own objectives, targets, and processes.As a sustainability-led university in Malaysia, USM aims to ensure that sustainability element is embedded in the overall teaching and research missions of the university (CGSS USM, n.d), thus this study would help the university in identifying the percentage of sustainability content embedded in the programme syllabus offered to its student. ,. The study focused on both arts and science programme offered in USM. For the purpose of this study, only 18 programmes out of 71 full-time programmes have been chosen as the subject matter due to time constraint as well as these programmes are the only programmes that have the current (year of 2016) and complete curriculum course synopsis book at the moment. 


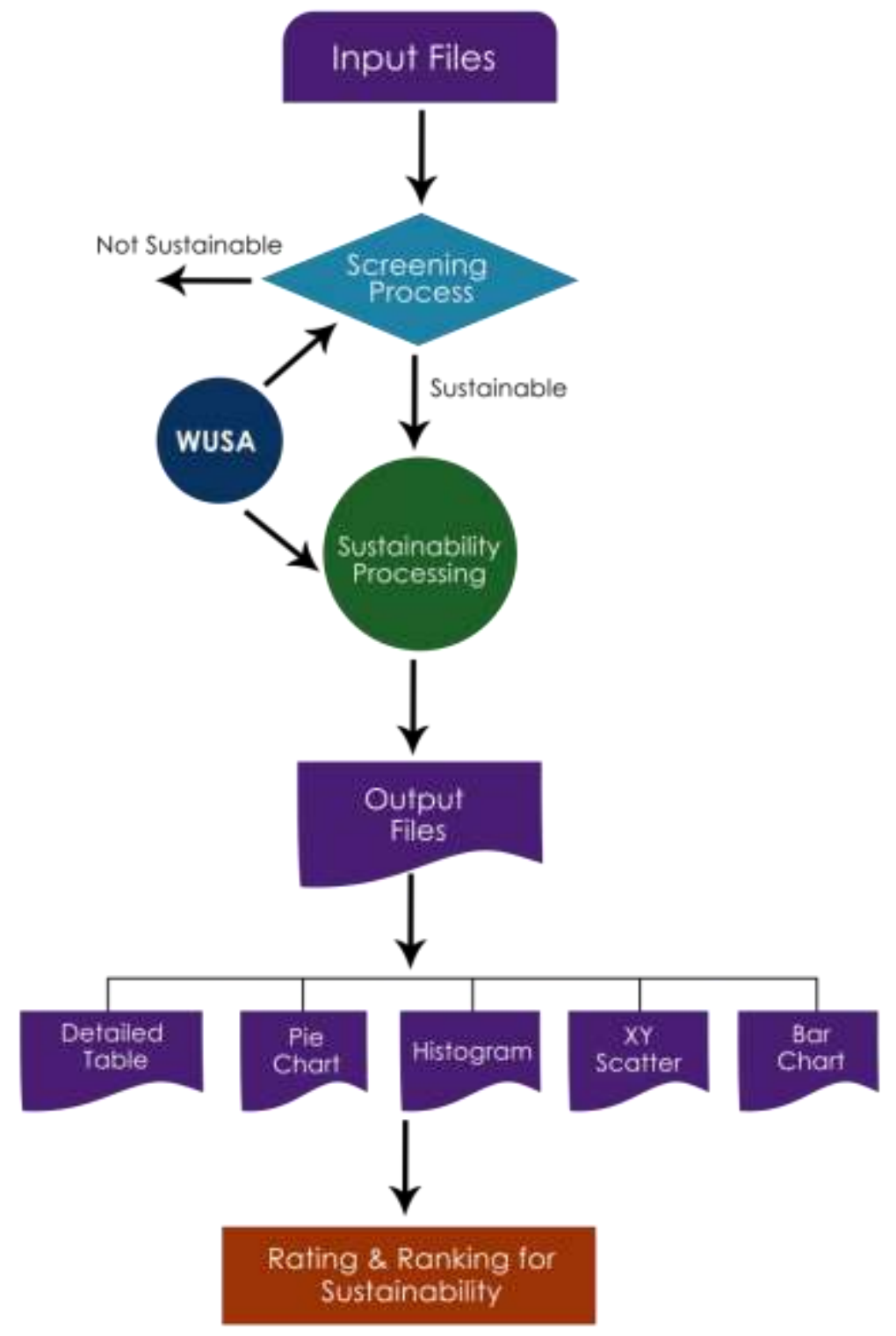

Figure 2 WUSA methodology flowchart

Figure 2 above illustrates the flowchart of how WUSA works. WUSA is a tool which is developed by using a PHP and Java languages, and MYSQL database. The keyword is extracted from some important documents which are related to sustainable development produced by reliable sources, mostly taken from the United Nations, which starts the sustainable development move to the public. The documents that have been used are listed as follows:

a) Stockholm Declaration (UN Conference on Human Environment, 1972)

b) Brundtland Commission Report (1987)

c) Agenda 21 (UN Conference on Environment and Development (Earth Summit), 1992)

d) Earth Charter (1994)

e) Johannersburg Plan of Implementation (UN, World Summit on Sustainable Development (WSSD, 2002) 
Vol. 8, No. 2, 2019, E-ISSN: 2226-6348 @ 2019 HRMARS

f) The Future We Want (UN Conference on Sustainable Development , 2012) and,

g) Other relevant national sustainability reports from government and civil society. The documents were uploaded into a software called IBM-SPSS to extract keywords and once extracted, each keyword which appeared the most in the documents was examined to ensure that the keyword is reliable for comparison. The keywords were then stored in a database for comparison purpose in the next phase. To check for sustainability percentage of a document, user will upload a document to the software. The software will then compare the uploaded document with the keywords stored in the database within seconds. The software will display the result once the document has been scanned and compared completely. The user can view the result in several views; pie chart, histogram, XY scatters chart, and bar chart for future analysis purpose. The result produced by WUSA can be used for ranking purpose; for instance, a competition held by a university which requires each school to run activities which contain the element of sustainability to the staff and students. Each school is required to produce a report which elaborates the activities that have been conducted and the university administration would then use the report and upload it to WUSA which can help produce the percentage of sustainability element of the report in a short period of time without having to screen each report manually.

\section{Result and Discussion}

In this study, WUSA has been used to determine the level of sustainability content of 18 programmes that are offered by schools in USM to prospective student. . Table 1 shows that, overall, the total percentage for the programmes being tested is below average.

Programme

Total Average of Sustainability

\begin{tabular}{ll} 
& (\%) \\
\hline Bachelor of Accounting & 1.51 \\
\hline Bachelor of Management & 1.64 \\
\hline Bachelor of Arts (Honours) English for Professionals & 6.08 \\
\hline Bachelor of Education Tesol & 6.85 \\
\hline Bachelor of Music & 7.06 \\
\hline Bachelor of Fine Arts (BFA) & 8.1 \\
\hline Bachelor of Engineering (Aerospace) & 10.44 \\
\hline Bachelor of Science with Education & 11.15 \\
\hline Bachelor of Pharmacy & 12.56 \\
\hline Bachelor of Economic & 12.9 \\
\hline Bachelor of Education (Special Education) & 13.73 \\
\hline Bachelor of Engineering (Civil) & 14.3 \\
\hline Bachelor of Arts & 15.8 \\
\hline Bachelor of Science (Housing, Building \& Planning) & 16.08 \\
\hline Bachelor of Social Sciences & 19.28 \\
\hline Bachelor of Technology & 21.79 \\
\hline Bachelor of Science & 22.61 \\
\hline Bachelor of Applied Science & 27.9
\end{tabular}

Table 1 Total average of sustainability for each course 
Vol. 8, No. 2, 2019, E-ISSN: 2226-6348 @ 2019 HRMARS

Based on Table 1, Bachelor of Accounting has the lowest score with a total average of $1.51 \%$ for its sustainability content while the Bachelor of Applied Science has the highest score with a total average of $27.9 \%$ for its sustainability content. The study furthered to investigate the percentage of sustainability element to understand which area of sustainability is scarce in the programmes.

\begin{tabular}{|c|c|c|c|c|c|}
\hline \multirow[b]{2}{*}{ Programme } & \multicolumn{5}{|c|}{ Sustainability Element Percentage (\%) } \\
\hline & Water & Energy & Health & $\begin{array}{l}\text { Agri- } \\
\text { culture }\end{array}$ & $\begin{array}{c}\text { Bio- } \\
\text { diversity }\end{array}$ \\
\hline Bachelor of Accounting & 5 & 0 & 0 & 0 & 3.57 \\
\hline Bachelor of Management & 5 & 0 & 0 & 0 & 3.57 \\
\hline $\begin{array}{l}\text { Bachelor of Arts (Honours) English } \\
\text { for Professionals }\end{array}$ & 0 & 0 & 2.63 & 0 & 10.72 \\
\hline Bachelor of Education Tesol & 2.5 & 2.63 & 2.63 & 0 & 7.15 \\
\hline Bachelor of Music & 5 & 2.63 & 2.63 & 2.5 & 7.15 \\
\hline Bachelor of Fine Arts & 2.5 & 0 & 2.63 & 2.5 & 7.15 \\
\hline Bachelor of Engineering (Aerospace) & 6.67 & 12.41 & 5.27 & 2.5 & 10.72 \\
\hline Bachelor of Science with Education & 6.67 & 18.61 & 2.63 & 0 & 14.29 \\
\hline Bachelor of Pharmacy & 7.5 & 2.63 & 10.4 & 7.5 & 28.75 \\
\hline Bachelor of Economic & 5 & 2.63 & 2.63 & 8.75 & 14.29 \\
\hline $\begin{array}{l}\text { Bachelor of Education (Special } \\
\text { Education) }\end{array}$ & 7.5 & 9.77 & 5.27 & 5.63 & 14.29 \\
\hline Bachelor of Engineering (Civil) & 25 & 8.83 & 5.27 & 5.63 & 10.72 \\
\hline Bachelor of Arts & 17.5 & 8.83 & 5.27 & 8.75 & 17.86 \\
\hline $\begin{array}{l}\text { Bachelor of Science (Housing, } \\
\text { Building \& Planning }\end{array}$ & 9.17 & 18.61 & 2.63 & 8.75 & 14.29 \\
\hline Bachelor of Social Sciences & 5 & 5.26 & 5.13 & 11.88 & 17.86 \\
\hline Bachelor of Technology & 21.67 & 16.73 & 2.63 & 25 & 21.43 \\
\hline Bachelor of Science & 14.17 & 27.45 & 7.9 & 28.75 & 35.72 \\
\hline Bachelor of Applied Science & 27.5 & 27.45 & 15.53 & 34.38 & 39.29 \\
\hline
\end{tabular}

Table 2 Total sustainability percentage based on WEHAB

WUSA is capable to calculate the sustainability percentage for different criteria namely Water, Energy, Health, Agriculture, and Biodiversity individually. This would eventually help schools to identify which criterion that the programme is lacking in and therefore, improve it. Table 2 shows the result of sustainability percentage for each criterion for each programme. For Water element, Bachelor of Technology has the highest percentage of sustainability with $27.5 \%$ of score while Bachelor of Arts (Honours) English for Professionals does not have any Water element in its syllabus. For Energy element, Bachelor of Science and Bachelor of Applied Science score 27.45\% while the syllabus Bachelor of Accounting, Bachelor of Management, and Bachelor of Arts (Honours) English for Professionals does not contain any Energy element. For Health element, the syllabus in Bachelor of Applied Science contains 15.53\% of Health element while the syllabus in Bachelor of Accounting and Bachelor of Management does not contain any Health related element. The syllabus in Bachelor of Applied Science also contains Agriculture and Biodiversity 
related elements. Meanwhile, Bachelor of Accounting, Bachelor of Management, Bachelor of Arts (Honours) English for Professionals, Bachelor of Education Tesol contains no Agriculture element in the syllabus. Bachelor of Accounting, Bachelor of Management, Bachelor of Arts (Honours) English for Professionals also only contain 3.57\% of Biodiversity element respectively.

A few courses which are offered by some of the programmes have contributed to the percentage of sustainability element. The courses offered by some of the programs which contain sustainability elements are "Sustainability: Issues and Challenges", "Social and Sustainable Computing", "Sustainable Entrepreneurship", and "Professional \& Technopreneurship Development". In "Sustainability: Issues and Challenges", students will be exposed to issues related to sustainability and how to build sustainability awareness among the public. Meanwhile, "Sustainable Entrepreneurship", and "Professional \& Technopreneurship Development" teach students in developing a business driven concept which contains sustainability element.

Based on the result shown, it can be concluded that the schools which offer the programmes should revise their curricula thoroughly to ensure that sustainability content is included into the syllabus. The schools need to ensure that all sustainability criteria are re-examined thoroughly. Therefore, appropriate actions should be made immediately to correct or improve on the percentage values and make their teaching curricula to be more sustainable. They may need to hold workshops, round table discussions, seminars and other various forms of discussions to resolve the low sustainability scores of their curricula. They should focus their discussions on the elements of sustainability to be incorporated into the synopses of the courses offered to students who enrol in any of the programmes.

It is highly recommended that the academicians in the university should monitor the course content from time to time to ensure that the materials that are taught to the students fulfil all the criteria of sustainability. They can utilize WUSA again to review the improved synopses to reasses the sustainability percentage scores. If the percentage scores of the elements of sustainability increase, then it shows the improvement of the sustainability element in the course. However, if the percentage score of the element of sustainability does not increase, then immediate actions must be taken to ensure that the course contest contains sustainability elements. This step may be repeated a few times until such time that the academic experts are satisfied with the percentage points obtained.

If the progress is not monitored, the implication is that the implementation of the designed programme would be difficult. Only then, the WUSA application developed will benefit the entire academic community. The benefits will accrue to, not only the local universities, but also to universities at the international level. WUSA is not only being used at the university but also in schools, whether public or private. In other words, WUSA will help the current education system to be more flattering with sustainability components. 
Vol. 8, No. 2, 2019, E-ISSN: 2226-6348 @ 2019 HRMARS

\section{Limitations \& Future Works}

The main limitation of the study is that the study only uses the programme book from each of the programme which contains the synopses of the programme and course content offered to prospective students. The synopsis is scanned to assess the percentage of sustainability content as a sample to introduce our WUSA tool to other sustainability practitioners. Thus, the result is arguable and in the future, the study would use lecturer's syllabus book or student's assignment for each course which is more comprehensive to ensure that the result of sustainability percentage is more reliable though the current result is still reliable as the course synopsis consists of the list of courses offered in each programme including the description of each course.

\section{Conclusion}

This study is conducted to introduce WUSA, a tool that has been developed to help universities or school that are moving towards incorporating sustainability element into the program courses. WUSA can help universities or school by calculating the percentage of sustainability elements in the course content document instantly. At the end of the assessment process, WUSA will produce result of the sustainability assessment which can be used for further analysis to improve the course content to contain more sustainability relevant topics. This study also presented how WUSA operates by presenting the result of sustainability assessment of 18 out of 71 programs which are offered in USM. The WUSA tool, which generated the result, showed that the percentage of sustainability element contained in the teaching courses for 18 programs are below average, which is less than $50 \%$.

After examining the course content of the programs manually, it is found that a few courses that are embedded in the programs have contributed to the sustainability percentage for some of the programs. One of the courses is a sustainability related course called "Sustainability: Issues and Challenges" in which the students are exposed to the issues on sustainability and on how to build sustainability awareness among the public. Other courses that contain some element of sustainability have also contributed to the sustainability percentage, namely "Sustainable Entrepreneurship" and "Professional \& Technopreneurship Development". USM should take prompt action to improve the teaching syllabus so that the syllabus would contain more sustainability relevant topics in order to shape students to be more conscious about and exposed to sustainability related issues which, in return, would contribute to the betterment of the future generations.

\section{References}

CGSS USM. (n.d). USM-APEX Sustainability Roadmap. Centre for Global Sustainability Studies, Universiti Sains Malaysia.

Hussin, S. (2004). Pendidikan di Malaysia: Sejarah, sistem dan falsafah. Kuala Lumpur, Malaysia: Dewan Bahasa dan Pustaka.

Ishak, I. Z. (2002). Kualiti pensyarah politeknik lepasan sarjana pendidikan Kolej Universiti Teknologi Tun Hussein Onn (KUiTTHO): Projek Sarjana Teknik dan Vokasional. KUiTTHO.

Majzub, R. (2005). Model latihan perguruan glokal untuk pembangunan lestari. Prosiding Seminar Pendidikan JPPG UKM, Bangi, Selangor, Malaysia. 
INTERNATIONAL JOURNAL OF ACADEMIC RESEARCH IN PROGRESSIVE EDUCATION AND DEVELOPMENT

Vol. 8, No. 2, 2019, E-ISSN: $2226-6348$ @ 2019 HRMARS

Mohamad, Z. F. (2001). Curriculum: Implementing education for sustainable development at the University Malaya. University Leaders for a Sustainable Development Future, 5(1). Retrieved from http://www.ulsf.org/ pub_declaration_curvol51.htm

Pavlova, M. (2004). Sustainable development: Is it an educational priority for French Students? In H. Middleton, M. Pavlova, \& D. Roebuck, (Eds.). Learning for innovation in technology education (vol. 3, pp. 36-45.) Proceeding of the 3rd International Conference on Technology Education Research: Centre for Learning Research, Griffith University.

Pavlova, M. (2006). Technology education for sustainable futures. Design and Technology Education: An International Journal, 11(2), 41-53.

Pavlova, M. (2008). Technology and vocational education: A framework for the development of teaching approaches and resources for education for sustainable development. In J. Fien, R. Maclean, \& M. G. Park (Eds.).Work, learning and sustainable development: Opportunities and challenges (Vol. 8, pp. 455-464). Dordrecht, Netherlands: Springer.

Pauw, J. B., Gericke, N., Olsson, D., Berglund, T. (2015). The Effectiveness of Education for Sustainable Development. Sustainability 2015, 7, 15693-15717; doi:10.3390/su71115693.

Razak, D. A. and Mohamed, R. (2008). Transforming Higher Education for a Sustainable Tomorrow. Universiti Sains Malaysia.

UNESCO-UNEVOC. (2004). Suggestions to UNESCO for action planning in TVET for sustainable development. Expert Meeting on Learning for Work, Citizenship and Sustainability, Bonn, October 2004. UNESCO, Paris. Retrieved from http://www.unevoc.unesco.org/fileadmin/user_upload/pubs/SD_BonnDeclaration_e.pdf

Yunos, J. M. (2004). View from the Field. UNESCO International Meeting on Innovation and Excellence in TVET Teacher/Trainer Education, 8-10 November 2004, Hangzhou, China. 